\title{
ЕФЕКТИВНІСТЬ АНТИБАКТЕРІАЛЬНОÏ ТЕРАПІЇ У ТЯЖКОХВОРИХ НА COVID-19 В ЗАЛЕЖНОСТІ ВІД ВІКУ ХВОРИХ ТА ДОЗ ГОРМОНАЛЬНИХ ПРЕПАРАТІВ
}

\author{
В.І. Трихліб, Т.І. Лисенко, А.О. Єрошенко, О.С. Мартинчик, \\ Н.Р. Цюрак, К.П.Бєляєва
}

Українська військово-медична академія, м. Київ, Україна

Вступ. У статті представлений огляд літератури стосовно ко-інфекцій при коронавірусній інфекції COVID-19 та приведені дані особистого дослідження стосовно антибактеріальної терапії у тяжкохворих nрu COVID-19.

Мета: встановити ефективність антибактеріальної терапії при лікуванні нової коронавірусної хвороби COVID-19 у тяжкохворих, які лікувались у BPIT, на фоні різних доз гормональної терапії та різних схем антибактеріальної терапії.

Матеріали та методи: оброблені дані 112 медичних карт стаціонарного хворого хворих з тяжким перебігом на нову корона вірусну хворобу COVID-19, які лікувались у ВРIT НВМКЦ «ГВКГ» в період з січня по квітень 2021 р. У всіх пацієнтів була виявлена пневмонія за допомогою рентгенографії органів грудної клітки або ж комп'ютерної томографії. У всіх хворих діагноз був підтверджений за допомогою ПЛР у реальному часі на PHK SARS-COV-2. Статистична обробка матеріалів дослідження проводилася за допомогою персонального комп'ютера з використанням програми STATISTICA. Було розроблено анкету для введення даних в програму Exсеl.

Результати. Встановлено, що серед тяжкохворих, які до госпіталізації приймали антибіотики, зареєстрована менша кількість летальних випадків (9,1\%), ніж у тих, хто антибіотики не приймав (29,3\%). У стаціонарі антибіотики призначали в термін пізніше 9 доби, тривалістю близько 7 діб. Переважно тяжкохворим у реанімації призначались або один, або два антибіотика. У нашій вибірці померлих у віці до 60 р. не було. За нашими даними, більше одужало хворих при застосуванні наступних схем антибактеріальної терапії: пеніциліни+фторхінолони; фторхінолони; карбапенеми. У хворих, які отримували, окрім антибіотиків, 8мг дексаметазону, було менше померлих на фоні застосування пеніциліни+фторхінолони; цефалоспорини+фторхінолони; карбапенеми. У інших хворих, які отримували, окрім антибіотиків, 16мг дексаметазону, менше було померлих на фоні застосування пеніциліни+фторхінолони; фторхінолони; карбапенеми. Зроблено висновок про необхідність подальших досліджень стосовно ефективності раннього призначення антибактеріальних препаратів (пеніциліни+фторхінолони, фторхінолони) у тяжкохворих та із середньою тяжкістю та розробки критеріїв призначення антибактеріальної терапії.

Висновки. Встановлено менше летальних випадків у тяжкохворих із COVID-19, які до госпіталізації приймали антибіотики, в порівнянні з тими, хто антибіотики не приймав. Із узагальнених даних щодо наслідків лікування із застосуванням антибактеріальних препаратів встановлена більшість летальних наслідків у тих, хто під час лікування отримував антибактеріальні препарати. В той же час встановлена дещо менша кількість померлих на фоні COVID-19, яким були призначені під час стаціонарного лікування 8 мг або 16мг дексаметазону та антибіотики із наступних схем: пеніциліни+фторхінолони, фторхінолони, карбапенеми. Потребує подальшого дослідження ефективність раннього призначення антибактеріальних препаратів (пеніциліни+фторхінолони, фторхінолони) у тяжкохворих та хворих із середньою тяжкістю. Слід розробити критерії призначення антибактеріальної терапії.

Ключові слова: COVID-19, тяжкохворі, антибактеріальна терапія.

Вступ. Нова коронавірусна інфекція COVID-19, не дивлячись на профілактичні заходи, залишається актуальною у країнах світу. У всьому світі станом на 18:47 CEST, 13 серпня 2021 року, В003 було зареєстровано 205 338159 підтверджених випадків COVID-19, у тому числі 4333094 смертей. Станом на 12 серпня 2021 року загалом було введено 4428 168759 доз вакцини [1].

При цьому захворюванні розвиваються різноманітні ускладнення, серед яких найбільш поширеним $\epsilon$ пневмонія. На жаль, на даний час недостатня лабораторна діагностика мікстінфекцій, бактеріальних інфекцій на фоні даного захворювання. Це викликає труднощі як в діагностиці, так і в лікуванні, з урахуванням того, що це захворювання має широкий спектр проявів, які можуть симулювати інші захворювання як вірусні, так і бактеріальні.

На даний час багато людей із легким перебігом захворювання COVID-19 без пневмонії або середньотяжким перебігом пневмонії отримують антибіотики. За різними даними, госпіталізованим хворим із COVID-19 
призначався принаймні один антибіотик або для профілактики, або з метою лікування, i лише у незначної кількості хворих були виявлені бактеріальні або грибкові коінфекції. Велика кількість досліджень показала, що під час пандемії COVID-19 призначення антибіотиків було надмірним під час лікування (до 90\% пацієнтам призначали емпірично антибіотики).

За даними Wenjing Wei, Jessica K. Ortwine, 2020, антибіотики були призначені при госпіталізації 59\% пацієнтам. 3 них з 85/87 (98\%) рецептів антибіотики були призначені емпірично. Найбільш поширеним показанням до емпіричного призначення антибіотиків було занепокоєння позалікарняною пневмонією (76/85, 89\%), при цьому найбільш часто призначали наступні антибіотики цефтріаксон та азитроміцин. Середня тривалість антибіотикотерапії становила два дні (міжквартильний діапазон 1-5). Жоден пацієнт не мав позалікарняної бактеріальної ко-інфекції дихальних шляхів, але у 10/147 (7\%) пацієнтів були виявлені одночасні бактеріальні інфекції 3 нереспіраторного джерела, одному пацієнту було поставлено діагноз «активний туберкульоз легенів» під час надходження до відділення для лікування COVID-19 [2].

Avnish Sandhu зі співавторами, 2020, 3 посиланням на різних авторів, відмічають, що в одноцентровому дослідженні 52 важкохворих пацієнтів було встановлено, що лікарняна інфекція була діагностовано лише у 7 (13,5\%) пацієнтів, проте 49 (94\%) пацієнтів отримували антибіотикотерапію. В іншому дослідженні, в якому було проаналізовано 113 померлих пацієнтів із 799 пацієнтів середнього та тяжкого ступеня тяжкості COVID-19 протягом 13 січня - 12 лютого 2020 року, було встановлено, що 105 (93\%) померлих пацієнтів та 144 (89\%) тих, хто одужав, отримали емпіричну антибактеріальну терапію або моксифлоксацином, або цефоперазоном, або азитроміцином [3].

В той же час під час пандемії COVID-19 клініцисти повинні пильно спостерігати за супутніми інфекціями у пацієнтів з COVID-19. Однак, на даний час види бактерій і грибків у пацієнтів з SARS-CoV-2 із ко-інфекцією досі повністю не досліджені і не зареєстровані.

Поширеність ко-інфекції $є$ різною серед пацієнтів з COVID-19 у різних дослідженнях, вона може становити до 50\% серед тих, хто не одужав. За результатами проведених досліджень, співпатогени включали бактерії, такі як: Streptococcus pneumoniae, Staphylococcus aureus, Klebsiella pneumoniae, Mycoplasma pneumoniae, Chlamydia pneumonia,Legionella pneumophila та Acinetobacter baumannii; Candida та Aspergillus flavus; та віруси, такі як: грип, коронавірус, риновірус/ентеровірус, парагрип, метапневмовірус, вірус грипу В та вірус імунодефіциту людини. Грип А був одним 3 найпоширеніших ко-інфекційних вірусів, який міг спричинити початкові хибнонегативні результати ПЛР при SARS-CoV-2 [4].

Як відмічають Waqas Ahmed Chauhdary зі співавторами, 2020, про первинну легеневу коінфекцію все частіше повідомляється при COVID-19, особливо це стосується респіраторних вірусів. Nowak et al. повідомили про 3\% респіраторних вірусних коінфекцій. Zhu et al. повідомили про вищі показники коінфекції. У дослідженні Waqas Ahmed Chauhdary зі співавторами, 2020, було перевірено 257 пацієнтів 3 COVID-19 на наявність респіраторних збудників та виявлено 24 типи респіраторних патогенів у 94,2\% хворих, з них Streptococcus pneumoniae, Klebsiella pneumoniae та Haemophilus influenzae були найпоширенішими збудниками. Також повідомлялося про коінфекцію мікобактеріями туберкульозу. Більшість ко-інфекцій відбулося протягом 1-4 днів після їх зараження. Важливо, що виділення респіраторних патогенів у мокроті не має різниці між колонізацією та клінічно значущою інфекцією. Ко-інфекція може призвести до затримки діагностики та менш сприятливих результатів [5].

За даними Bradley J.Langford зі співавторами, із 1308 перевірених досліджень, 24 були прийнятні і представляли 3338 пацієнтів з COVID-19 із даними про гостру бактеріальну інфекцію. у мета-аналізі бактеріальна ко-інфекція була виявлена у $3,5 \%$ пацієнтів (95\%ДІ 0,4-6,7\%), а вторинна бактеріальна інфекція - у 14,3\%пацієнтів (95\%ДІ 9,6-18,9\%). Загальна частка хворих на COVID-19 з бактеріальною інфекцією становила 6,9\% (95\%ДІ 4,3-9,5\%). Бактеріальна інфекція була більш поширеною у важкохворих $(8,1 \%$, 95\%ДІ 2,3-13,8\%) [6].

За результатами іншого дослідження Xi Chen зі співавторами, 2020, вірусна ко-інфекція зазвичай включала респіраторний вірус, такий як: ентеро/риновірус (hRV), метапневмовірус людини (hMPV), респіраторно-синцитіальний вірус (RSV) та інший коронавірус (nonCOVID-19) (Lin et al., 2020 ). Ко-інфекція також може 
змінити гомеостаз кишковика, таким чином запускаючи інфекцію, i викликати більш серйозне запалення. Gu et al., 2020, нещодавно виявили, що кишкова бактеріальна різноманітність у хворих з COVID-19 значно зменшується, відносно велика кількість умовно-патогенних мікроорганізмів, таких як: Streptococcus, Rothia, Veillonella i Actinomyces значно вище, в той час як відносно корисних симбіонтів,

таких як: Blautia, Romboutsia, Collinsella i Bifidobacteriu $m$ - нижче. Дослідження, яке було проведене Chen et al., 2020, показало, що ко-інфіковані гриби включають Aspergillus spp., Candida albicans та Candida glabrata. Netea et al., 2020, виявили, що у більшості людей інфекція SARSCoV-2 є легкою, тоді як ко-інфекція може збільшити сприйнятливість пацієнтів до важких захворювань, впливаючи на імунну функцію організму [7].

За даними іншого дослідження при SARSCoV-2, яке включало 55 тяжких пацієнтів та 166 пацієнтів нетяжких 3 лабораторно підтвердженою пневмонією SARS-CoV-2, Zhang et al. (2020), виявили, що у всіх 221 пацієнта рівень бактеріальної ко-інфекції становить 7,7\%, а рівень грибкової ко-інфекції - 3,2\%. При іншій вірусній пневмонії, рівень ко-інфекції у важких пацієнтів значно вищий, ніжу нетяжких пацієнтів (Choi et al. 2012). У дослідженні Guqin Zhang's встановлено, що у тяжкохворих значно вищий рівень ко-інфекції бактеріями $(25,5 \%)$ та грибками $(10,9 \%)$, тоді як рівень бактеріальної та грибкової ко-інфекції у нетяжких пацієнтів становить $0,8 \%$ та 0,6\%, відповідно. Дослідження в Італії показало, що серед 16654 пацієнтів 3 найважчими захворюваннями, які померли від інфекції SARS-CoV-2, у 11\% цих випадків була виявлена ко-інфекція іншими бактеріями та грибами (Huttner et al., 2020 ). Ко-інфекція бактеріями та грибами має великий вплив на прогресування та прогноз захворювання, особливо у важких пацієнтів, що може призвести до збільшення потреб в інтенсивній терапії, лікуванні антибіотиками та збільшення смертності (Kiedrowski and Bomberger 2018; Lim et al. 2019 ). Бактеріальна та грибкова ко-інфекція пов'язана з 2,5-кратним збільшенням ризику смерті від SARS-CoV-2 (Martins-Filho et al. 2020) [8].

Відомо що ко-інфекції можуть призвести до затримки діагностики та менш сприятливих результатів. Тому ми рекомендуємо емпіричне лікування, засноване на клінічних симптомах пацієнтів 3 коронавірусом, вибираючи найбільш підходящий антибактеріальний препарат відповідно до місцевих рекомендацій, місцевої чутливості, і якомога раніше скорегувати АБ на підставі мікробіологічних результатів або припинити неправильне застосування антибіотиків [8].

При лікування часто призначались різноманітні антибіотики, часто фторхінолони та цефалоспоринів третього покоління. При дослідженні у Швейцарії було встановлено, що антибіотики перед госпіталізацією отримували $40 \%$ хворих, у всіх випадках клінічним показанням була підозра на бактеріальну коінфекцію. Найбільш часто призначався амоксицилін / клавуланат (68\%). Авторами зроблено висновок, що антибіотики, які вводяться на ранній стадії, суттєво не впливають на смертність або затримку розвитку госпітальних інфекцій у важкохворих [9].

Мета дослідження: встановити ефективність антибактеріальної терапії при лікуванні нової коронавірусної хвороби COVID19 у тяжкохворих, які лікувались у ВРIT, на фоні різних доз гормональної терапії та різних схем антибактеріальної терапії.

Матеріали та методи дослідження. Оброблені дані 112 медичних карт стаціонарного хворого, хворих 3 тяжким перебігом на нову корона вірусну хворобу COVID-19, які лікувались у BPIT НВМКЦ «ГВКГ» в період з січня по квітень 2021 р. У всіх пацієнтів була виявлена пневмонія за допомогою рентгенографії органів грудної клітки або ж комп'ютерної томографії. У всіх хворих діагноз був підтверджений за допомогою ПЛР у реальному часі на PHK SARSCOV-2.

Статистична обробка матеріалів дослідження проводилася за допомогою персонального комп'ютера з використанням програми STATISTICA. Було розроблено анкету для введення даних в програму Excel. Віковий розподіл всіх хворих, які лікувались у вріт НВМКЦ «ГВКГ» наведено в попередній роботі «Клініко-лабораторні показники у хворих, які лікувались у ВРІТ НВМКЦ «ГВКГ» 3 приводу COVID-19»: 1 група - 20-29 років, 2 група - 30-39 років, 3 група - 40-49 років, 4 група - 50-59 років, 4 група - 60-69 років, 5 група - 70-79 років, 6 група - 80-89 років, 7 група - 90 і більше років. 
Результати дослідження та їх обговорення. Було встановлено наступне застосування антибіотиків до госпіталізації: цефтріаксон приймав 1 хворий, сумамед - 3, азитроміцин - 2, аугментин - 1, азимед - 1 , амоксил - 1, супракс - 1, лефлоцин - 1, амоксил К +левофлоксацин - 1, цефподоксим - 1 .

Із 11 осіб, які до госпіталізації приймали антибіотик: помер - 1 (9,1\%), одужало - 10 (90,9\%). Серед 99 хворих, які до госпіталізації антибіотики не приймали: померло - 29 (29,3\%), одужало - 70 (70,7\%) хворих.

3 урахуванням того, що одним із критеріїв бактеріальної інфекції та підгрунтям для призначення антибактеріальної терапії був лейкоцитоз, гранулоцитоз, ми провели дослідження стосовно виявлення частоти даних лабораторних змін. Встановлено, що у хворих з лейкоцитозом в перші три дні після госпіталізації були наступні наслідки: 8 (28,6\%) померло, 20 (71,4\%) одужало; у хворих 3 нормоцитозом - 18 (25,7\%) померло, 52 $(74,3 \%)$ одужало, 3 лейкопенією - 5 (41,7\%) померло, 7 (58,3\%) одужало.

Далі представляємо сумарні дані по наслідкам у хворих в залежності від віку, змін у крові та прийому антибактеріальних препаратів.

Хворих у віці до 60 років із лейкоцитозом було 12 (27,3\%), із нормоцитозом - 28 (63,6\%), із лейкопенією - 4 (9,1\%) хворих. Хворих молодше 60 років, які приймали антибіотики, із лейкоцитозом було 4 (33,3\%), нормоцитозом - 7 (58,3\%), лейкопенією - 1 (8,3\%). Хворих старше 60 років із лейкоцитозом було 16 (24,2\%), нормоцитозом - 42 (63,6\%), лейкопенією - 8 $(12,1 \%)$. Хворих старше 60 років, які приймали антибіотики, із лейкоцитозом було 11 (34,4\%), нормоцитозом - 18 (56,3\%), лейкопенією - 3 $(9,4 \%)$.

У хворих старше 60p., які отримували антибіотики та у яких був лейкоцитоз, померло 7 (63,6\%) хворих, одужало 4 (36,4\%) хворих; у яких був нормоцитоз - померло 9 (50\%), одужало 9 (50\%) хворих; у яких була лейкопенія - померло 3 (60\%) хворих, одужало 2 (40\%) хворих.

у хворих старше 60 р., які не отримували антибіотики та у яких був лейкоцитоз, помер 1 (20\%) хворий, одужало 4 (80\%) хворих; у яких був нормоцитоз померло 8 (33,3\%), одужало 16 (66,7\%) хворих; у яких була лейкопенія - померло 2 (66,7\%) хворих, одужав 1 (33,3\%) хворий.
У хворих старше 60 р., які отримували антибіотики та у яких був гранулоцитоз, померло 12 (63,2\%) хворих, одужало 7 (36,8\%) хворих; у яких була нормальна кількість гранулоцитів - померло 7 (50\%), одужало 7 (50\%) хворих; у яких була гранулоцитопенія померлих не було, 1 хворий одужав.

У хворих старше 60 р., які не отримували антибіотики та у яких був гранулоцитоз, померло 8 (42,1\%) хворих, одужало 11 (57,9\%) хворих; у яких була нормальна кількість гранулоцитів - померло 3 (23,1\%), одужало 10 (76,9\%) хворих; у яких була гранулоцитопенія - таких хворих не було.

У хворих старше 60 р., які отримували антибіотики та у яких була підвищена кількість паличкоядерних нейтрофілів, померло 8 (66,7\%) хворих, одужало 4 (33,3\%) хворих; у яких була нормальна кількість паличкоядерних нейтрофілів - помер 1 (25\%) хворий, одужало 3 (75\%).

У хворих старше 60 р., які не отримували антибіотики та у яких була підвищена кількість паличкоядерних нейтрофілів, померло 3 (37,5\%) хворих, одужало 5 (62,5\%) хворих; у яких була нормальна кількість паличкоядерних нейтрофілів - померлих не було, одужало - 4 хворих.

Серед 48 осіб, які під час госпіталізації приймали антибіотик: померло - 20 (41,7\%), одужало - 28 (58\%). Серед 64 хворих, які під час госпіталізації антибіотики не приймали: померло - 12 (18,8\%), одужало - 52 (81,25\%) хворих.

Під час госпіталізації хворим було призначено: по 1 антибіотику - 22 (45,8\%) хворим, 2 антибіотика - 22 (45,8\%) хворим, 3 антибіотика - $2(4,2 \%)$ хворим, 4 антибіотика $2(4,2 \%)$ хворим.

Серед тих, хто приймав 1 антибіотик, померло 9 хворих, 13 одужало. Серед тих, хто приймав 2 антибіотика, 11 померло, 11 одужало. Серед тих, хто приймав 3 антибіотика, 2 одужало. Серед тих, хто приймав 4 антибіотика, 2 одужало.

На рис. 1 представлений розподіл схем антибактеріальної терапії у тяжкохворих, які лікувались у BPIT.

Хворим, які померли, були призначені наступні антибактеріальні препарати та їх комбінації: препарат із групи пеніциліни+фторхінолон - 1 хворому, цефалоспорини+фторхінолони - 7 хворим, фторхінолони - 3 хворим, цефалоспорини - 6 хворим, інші - 3 хворим; хворим, які одужали 
були призначені: пеніциліни+фторхінолони 6 хворим, цефалоспорини+фторхінолони - 3 хворим, фторхінолони - 9 хворим, цефалоспорини - 1 хворому, карбапенеми в комбінації з іншими препаратами - 5 хворим, інші - 4 хворим.
В наступній таблиці 1 представлені дані щодо тривалості ліжко-дня в залежності від схем антибактеріальної терапії, які більше всього призначались тяжкохворим.

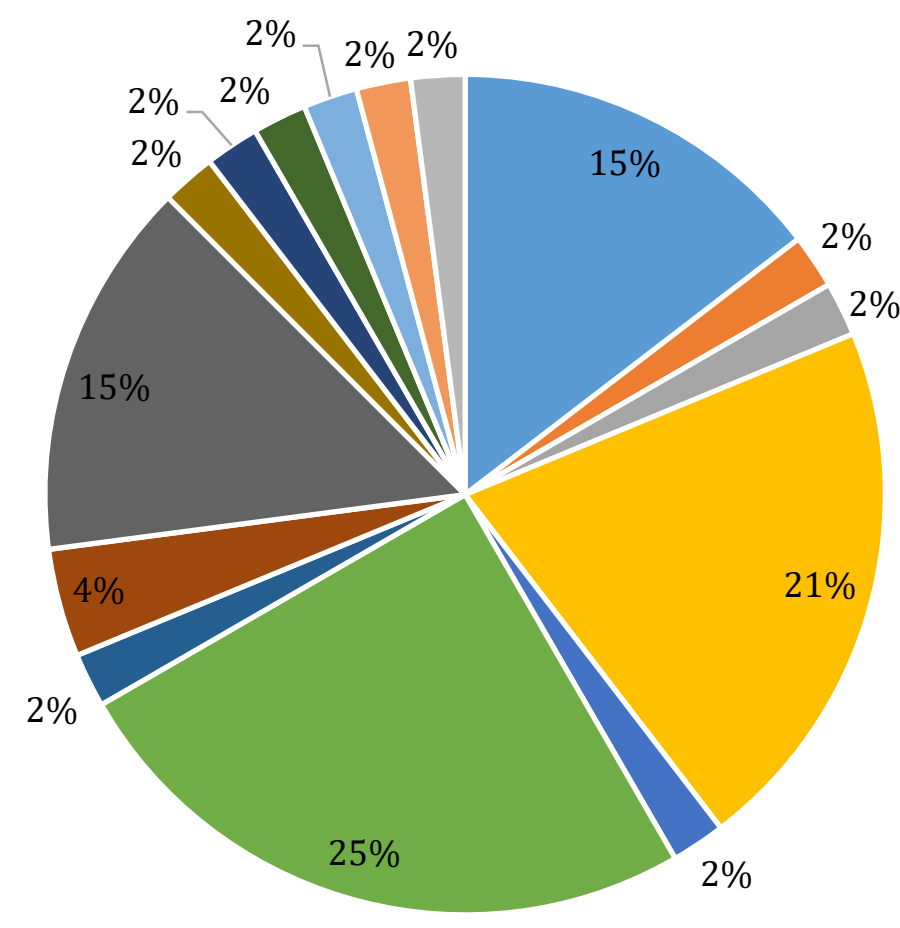

• Пеніциліни+фторхінолони

- Цефал+Фторх+Карбап+Глік опептид

- Аміноглік+цефалосп

- Фторхінол+Цефал

- Пеніц+Фторх+Карбап+Гліко пепт

- Фторхінол

- Цефал+Фторх+Пеніц

- Пеніц

• Цефал

- Цефал+мМакрол

- Пеніц+Цефал

- Карбап

- Аміногл+Цефал

- Фторхін+Карбапен

• Фторх+Глікопеп+Карбапен

Рисунок 1. Розподіл схем антибактеріальної терапії у тяжкохворих, які лікувались у ВРІT.

Таблиця 1

Ліжко-день та наслідки хвороби в залежності від схем антибактеріальної терапії у 112 тяжкохворих, які лікувались у ВРІТ НВМКЦ «ГВКГ» в період січень-квітень 2021р

\begin{tabular}{|c|c|c|}
\hline \multirow{2}{*}{$\begin{array}{c}\text { Антибактеріальна } \\
\text { терапія, схеми } \\
\end{array}$} & \multicolumn{2}{|c|}{ Ліжко-день } \\
\hline & Одужавші & Померлі \\
\hline 1 & $\begin{array}{c}\mathrm{Me}=21,5\left(\mathrm{Q}_{25}=16, \mathrm{Q}_{75}=26\right), \min =10 \\
\max =34\end{array}$ & $\mathrm{Me}=7$ \\
\hline 2 & $\mathrm{Me}=27\left(\mathrm{Q}_{25}=21, \mathrm{Q}_{75}=49\right), \min =21, \max =49$ & $\begin{array}{c}\mathrm{Me}=18\left(\mathrm{Q}_{25}=11, \mathrm{Q}_{75}=21\right), \min =2, \\
\max =21\end{array}$ \\
\hline 3 & $\mathrm{Me}=19\left(\mathrm{Q}_{25}=16, \mathrm{Q}_{75}=22, \min =12, \max =38\right.$ & $\begin{array}{c}\mathrm{Me}=12\left(\mathrm{Q}_{25}=2, \mathrm{Q}_{75}=20\right), \min =2, \\
\max =20\end{array}$ \\
\hline 4 & $\mathrm{Me}=13$ & $\begin{array}{c}\mathrm{Me}=11\left(\mathrm{Q}_{25}=9, \mathrm{Q}_{75}=15\right), \min =8, \\
\max =32\end{array}$ \\
\hline 5 & $\mathrm{Me}=27\left(\mathrm{Q}_{25}=23, \mathrm{Q}_{75}=31, \min =13, \max =33\right.$ & $\begin{array}{c}\mathrm{Me}=11\left(\mathrm{Q}_{25}=9, \mathrm{Q}_{75}=15\right), \min =8, \\
\max =32\end{array}$ \\
\hline 6 & $\begin{array}{c}\mathrm{Me}=16,5\left(\mathrm{Q}_{25}=8,5, \mathrm{Q}_{75}=25\right), \min =2, \\
\max =32\end{array}$ & $\begin{array}{c}\mathrm{Me}=17\left(\mathrm{Q}_{25}=2, \mathrm{Q}_{75}=28\right), \min =2, \\
\max =28)\end{array}$ \\
\hline
\end{tabular}

Примітка: 1 група - Пеніциліни+фторхінолони; 2 група - Фторхінолони+цефалоспорини; 3 група Фторхінолони; 4 група - Цефалоспорини; 5 група - Карбапенеми+інші; 6 група - інші. 
Із хворих, які отримували антибіотики №1 групи, помер 1, 6 одужало; із тих, хто отримував антибіотики №2 групи, померло 7, 3 одужало; групи №3 - померло 3, одужало - 9; групи №4 - померло 6, одужало - 1; групи №5
- померло 0, одужало - 5; групи №6 - померло 3, одужало - 4 .

В наступній таблиці 2 представлені дані щодо наслідків лікування в залежності від віку та схем антибактеріальної терапії.

Таблиця 2

Результати лікування хворих в залежності від віку та схеми антибактеріальної терапії

\begin{tabular}{|c|c|c|c|c|c|c|c|c|c|c|c|c|}
\hline \multirow{3}{*}{ 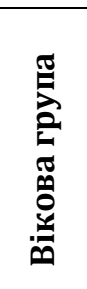 } & \multicolumn{12}{|c|}{ Схеми антибіотиків } \\
\hline & \multicolumn{2}{|c|}{ №1 } & \multicolumn{2}{|c|}{ №2 } & \multicolumn{2}{|c|}{ №3 } & \multicolumn{2}{|c|}{\begin{tabular}{|r|} 
№4 \\
\end{tabular}} & \multicolumn{2}{|c|}{ №5 } & \multicolumn{2}{|c|}{ №6 } \\
\hline & 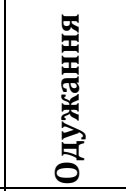 & $\begin{array}{l}\text { 离 } \\
\text { हैं }\end{array}$ & 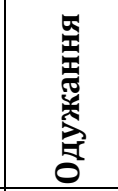 & $\begin{array}{l}\hat{\mathrm{E}} \\
\text { हैँ } \\
\text { हुँ }\end{array}$ & 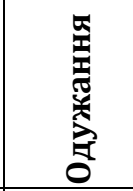 & $\begin{array}{l}\text { है } \\
\text { हूँ } \\
\text { हु }\end{array}$ & 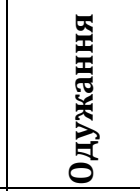 & 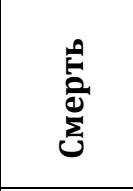 & 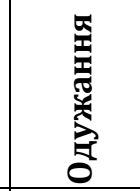 & $\begin{array}{l}\hat{E} \\
\text { है } \\
\text { है }\end{array}$ & 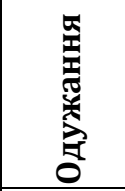 & $\begin{array}{l}\hat{0} \\
\text { हैँ } \\
\text { है }\end{array}$ \\
\hline 1 & 0 & 0 & 0 & 0 & 0 & 0 & 0 & 0 & 0 & 0 & 0 & 0 \\
\hline 2 & 0 & 0 & 0 & 0 & 1 & 0 & 0 & 0 & 1 & 0 & 0 & 0 \\
\hline 3 & 1 & 0 & 0 & 0 & 2 & 0 & 0 & 0 & 1 & 0 & 2 & 0 \\
\hline 4 & 3 & 0 & 0 & 0 & 1 & 0 & 0 & 0 & 1 & 0 & 0 & 0 \\
\hline 5 & 1 & 0 & 1 & 2 & 3 & 0 & 0 & 1 & 1 & 0 & 1 & 1 \\
\hline 6 & 1 & 0 & 1 & 6 & 1 & 0 & 0 & 3 & 1 & 0 & 1 & 0 \\
\hline 7 & 0 & 1 & 1 & 1 & 1 & 3 & 1 & 2 & 0 & 0 & 0 & 2 \\
\hline 8 & 0 & 0 & 0 & 0 & 0 & 0 & 0 & 0 & 0 & 0 & 0 & 0 \\
\hline $\begin{array}{l}\text { до } \\
60 \\
\end{array}$ & $\begin{array}{c}4 \\
(100 \%) \\
\end{array}$ & 0 & 0 & 0 & $\begin{array}{c}4 \\
(100 \%) \\
\end{array}$ & 0 & 0 & 0 & $\begin{array}{c}3 \\
(100 \%) \\
\end{array}$ & 0 & $\begin{array}{c}2 \\
(100 \%)\end{array}$ & 0 \\
\hline$>60$ & $\begin{array}{c}2 \\
(66,7 \%)\end{array}$ & $\begin{array}{c}1 \\
(33,3 \%) \\
\end{array}$ & $\begin{array}{c}3 \\
(25 \%)\end{array}$ & $\begin{array}{c}9 \\
(75 \%)\end{array}$ & $\begin{array}{c}5 \\
(62,5 \%)\end{array}$ & $\begin{array}{c}3 \\
(37,5 \%)\end{array}$ & $\begin{array}{c}1 \\
(14,3 \%)\end{array}$ & $\begin{array}{c}6 \\
(85,7 \%) \\
\end{array}$ & $\begin{array}{c}2 \\
(100 \%)\end{array}$ & $\begin{array}{l}0 \\
0 \\
\end{array}$ & $\begin{array}{c}2 \\
(40 \%)\end{array}$ & $\begin{array}{c}3 \\
(60 \%)\end{array}$ \\
\hline
\end{tabular}

Примітки: Вікові групи: 1 - 20-29 років, 2 - 30-39 років, 3 - 40-49 років, 4 - 50-59 років, 5 - 60-69 років, 6 - 70-79 років, 7 - 80-89 років, 8 - 90 і більше років. Схеми АБ: №1 - пеніциліни+фторхінолони; №2 цефалоспорини+фторхінолони; №3 - фторхінолони; №4 - цефалоспорини; №5 - карбапенеми; №6 - інші.

3 даної таблиці видно, що більше одужало при застосуванні наступних схем антибактеріальної терапії: №1, №3, №5, №6.

3 урахуванням того, що антибіотики призначались на фоні різних доз дексаметазону, що також могло вплинути на наслідки лікування, провели дослідження стосовно наслідків лікування на фоні 8 та 16мг дексаметазону у різних вікових групах (табл. 3 та 4). Показано, що , менше осіб померло на фоні застосування дексаметазону 8мг та схем антибактеріальної терапії: №1, №2, №5, №6.

Далі представлені дані щодо наслідків лікування різними схемами антибактеріальних препаратів на фоні 16мг дексаметазону (табл. 4). Тут видно, що більше одужало на фоні 16мг дексаметазону при застосуванні наступних схем антибактеріальної терапії: №1, №3, №5, №6.

Загалом із 17 хворих старше 60, які отримували 8мг дексаметазону + антибактеріальні препарати, померло 8 $(47,06 \%)$ хворих; із 15 хворих, які отримували 16мг дексаметазону +антибактеріальні препарати, померло 10 (66,7\%) хворих.

Препарати із групи пеніцилінів були призначені 12 хворим, з них: 2 хворих, які в наступному померли, та 10 хворих одужали. Доба призначення антибіотиків 3 групи пеніцилінів та схем, куди входять дані препарати - $\mathrm{Me}=15\left(\mathrm{Q}_{25}=10,5, \mathrm{Q}_{75}=16\right), \min =6$, $\max =24$ доба. Препарати призначались тим, хто одужав - на $\mathrm{Me}=15\left(\mathrm{Q}_{25}=9, \mathrm{Q}_{75}=17\right), \min =6$, $\max =24$ добу, тим, хто помер - $\mathrm{Me}=13,5$ $\left(\mathrm{Q}_{25}=12, \mathrm{Q}_{75}=15\right), \quad \min =12, \quad \max =15$ добу. Тривалість призначення - $\mathrm{Me}=7\left(\mathrm{Q}_{25}=4, \mathrm{Q}_{75}=9\right)$, $\min =2$, $\max =15$ діб. Температура на момент призначення $-\mathrm{Me}=37,15^{\circ} \mathrm{C}\left(\mathrm{Q}_{25}=36,65^{\circ} \mathrm{C}\right.$, $\mathrm{Q}_{75}=37,75^{\circ} \mathrm{C}$ ), $\quad \min =36,2^{\circ} \mathrm{C}, \quad \max =38,7^{\circ} \mathrm{C}$. Тривалість температури на фоні лікування антибіотиками пеніцилінової групи, або схем куди входять дані препарати - $\mathrm{Me}=7\left(\mathrm{Q}_{25}=4\right.$, $\mathrm{Q}_{75}=9$ ), $\min =2, \max =15$ діб. Сатурація на день призначення антибактеріального лікування $\mathrm{Me}=96 \% \quad\left(\mathrm{Q}_{25}=94 \%, \mathrm{Q}_{75}=97 \%\right), \quad \mathrm{min}=89 \%$, $\max =98 \%$. Доба нормалізації сатурації $-\mathrm{Me}=2$ доба $\left(\mathrm{Q}_{25}=0, \mathrm{Q}_{75}=15\right), \quad \min =0, \max =16$ діб. Частота дихання на момент призначення - Ме $=20 /$ хв $\left(Q_{25}=18, Q_{75}=22,5\right), \min =16, \max =27 /$ хв. Доба нормалізації частоти дихання - $\mathrm{Me}=2$ доба $\left(Q_{25}=0, Q_{75}=4\right), \min =0, \max =12$ діб. Частота пульсу на момент призначення $-\mathrm{Me}=75 / \mathrm{xв}$ $\left(\mathrm{Q}_{25}=70, \quad \mathrm{Q}_{75}=82\right), \quad \min =66, \quad \max =85 /$ хв. Нормалізація пульсу протягом 1 доби. 
Таблиця 3

Результати лікування хворих в залежності від віку, схеми антибіотиктеріальної терапії на фоні застосування 8мг дексаметазону

\begin{tabular}{|c|c|c|c|c|c|c|c|c|c|c|c|c|}
\hline \multirow{3}{*}{ 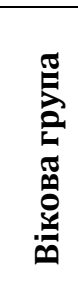 } & \multicolumn{12}{|c|}{ Схеми антибіотиків } \\
\hline & \multicolumn{2}{|c|}{ №1 } & \multicolumn{2}{|c|}{ №2 } & \multicolumn{2}{|c|}{ №3 } & \multicolumn{2}{|c|}{ №4 } & \multicolumn{2}{|c|}{ №5 } & \multicolumn{2}{|c|}{ №6 } \\
\hline & 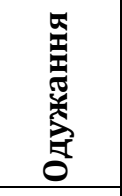 & 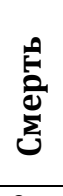 & 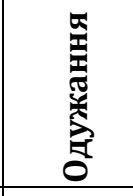 & $\begin{array}{l}\text { है } \\
\text { हैं } \\
\text { है }\end{array}$ & 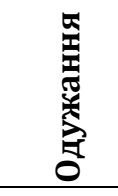 & 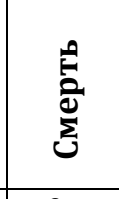 & 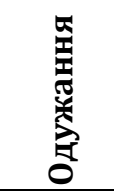 & $\begin{array}{l}\text { है } \\
\text { है } \\
\text { हूँ }\end{array}$ & 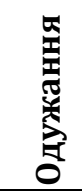 & 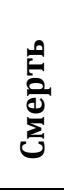 & 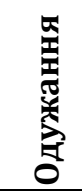 & $\begin{array}{l}\text { है } \\
\text { हैं }\end{array}$ \\
\hline 1 & 0 & 0 & 0 & 0 & 0 & 0 & 0 & 0 & 0 & 0 & 0 & 0 \\
\hline 2 & 0 & 0 & 0 & 0 & 0 & 0 & 0 & 0 & 0 & 0 & 0 & 0 \\
\hline 3 & 0 & 0 & 0 & 0 & 0 & 0 & 0 & 0 & 0 & 0 & 0 & 0 \\
\hline 4 & 1 & 0 & 0 & 0 & 2 & 0 & 0 & 0 & 0 & 0 & 0 & 0 \\
\hline 5 & 0 & 0 & 2 & 0 & 1 & 0 & 0 & 1 & 1 & 0 & 0 & 0 \\
\hline 6 & 1 & 0 & 1 & 1 & 0 & 0 & 0 & 0 & 0 & 0 & 1 & 0 \\
\hline 7 & 0 & 0 & 1 & 1 & 0 & 3 & 1 & 2 & 0 & 0 & 0 & 0 \\
\hline 8 & 0 & 0 & 0 & 0 & 0 & 0 & 0 & 0 & 0 & 0 & 0 & 0 \\
\hline $\begin{array}{l}\text { до } \\
60\end{array}$ & $\begin{array}{c}1 \\
(100 \%)\end{array}$ & 0 & 0 & 0 & $\begin{array}{c}2 \\
(100 \%) \\
\end{array}$ & 0 & 0 & 0 & 0 & 0 & 0 & 0 \\
\hline$>60$ & $\begin{array}{c}1 \\
(100)\end{array}$ & 0 & $\begin{array}{c}4 \\
(66,7 \%)\end{array}$ & $\left(\begin{array}{c}2 \\
(33,3 \%)\end{array}\right.$ & $\begin{array}{c}1 \\
(25 \%)\end{array}$ & $\begin{array}{c}3 \\
(75 \%)\end{array}$ & $\begin{array}{c}1 \\
(25 \%)\end{array}$ & $\begin{array}{c}3 \\
(75 \%)\end{array}$ & $\begin{array}{c}1 \\
100 \\
\end{array}$ & 0 & $\begin{array}{c}1 \\
100\end{array}$ & 0 \\
\hline
\end{tabular}

Примітки: Вікові групи: 1 - 20-29 років, 2 - 30-39 років, 3 - 40-49 років, 4 - 50-59 років, 5 - 60-69 років, 6 - 70-79 років, 7 - 80-89 років, 8 - 90 і більше років. Схеми АБ: №1 - пеніциліни+фторхінолони; №2 цефалоспорини+фторхінолони; №3 - фторхінолони; №4 - цефалоспорини; №5 - карбапенеми; №6 - інші.

Таблиця 4

Результати лікування хворих в залежності від віку, схеми антибактеріальної терапії на фоні застосування 16 мг дексаметазону

\begin{tabular}{|c|c|c|c|c|c|c|c|c|c|c|c|c|}
\hline \multirow{3}{*}{ 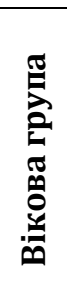 } & \multicolumn{12}{|c|}{ Схеми антибіотиків } \\
\hline & \multicolumn{2}{|c|}{ №1 } & \multicolumn{2}{|c|}{ №2 } & \multicolumn{2}{|c|}{$\begin{array}{l}\text { №3 } \\
\end{array}$} & \multicolumn{2}{|c|}{ №4 } & \multicolumn{2}{|c|}{ №5 } & \multicolumn{2}{|c|}{ №6 } \\
\hline & 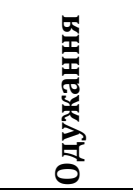 & $\begin{array}{l}\overrightarrow{0} \\
\overrightarrow{0} \\
\vec{j}\end{array}$ & 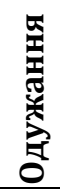 & $\begin{array}{l}\hat{E} \\
\overrightarrow{0} \\
\overrightarrow{0}\end{array}$ & 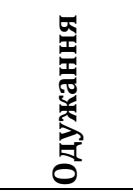 & $\begin{array}{l}\text { है } \\
\text { है } \\
\text { है }\end{array}$ & 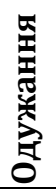 & 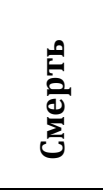 & 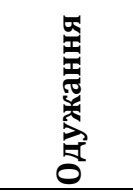 & $\begin{array}{l}\overrightarrow{0} \\
\text { हैँ } \\
\text { है }\end{array}$ & 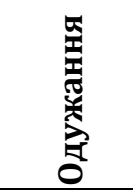 & $\begin{array}{l}\overrightarrow{0} \\
\overrightarrow{0} \\
\text { हैं }\end{array}$ \\
\hline 1 & 0 & 0 & 0 & 0 & 0 & 0 & 0 & 0 & 0 & 0 & 0 & 0 \\
\hline 2 & 0 & 0 & 0 & 0 & 1 & 0 & 0 & 0 & 1 & 0 & 0 & 0 \\
\hline 3 & 1 & 0 & 0 & 0 & 2 & 0 & 0 & 0 & 1 & 0 & 2 & 0 \\
\hline 4 & 2 & 0 & 0 & 0 & 0 & 0 & 0 & 0 & 1 & 0 & 0 & 0 \\
\hline 5 & 1 & 0 & 0 & 2 & 1 & 0 & 0 & 0 & 0 & 0 & 1 & 1 \\
\hline 6 & 0 & 0 & 0 & 2 & 1 & 0 & 0 & 3 & 1 & 0 & 0 & 0 \\
\hline 7 & 0 & 1 & 0 & 0 & 0 & 0 & 0 & 0 & 0 & 0 & 0 & 1 \\
\hline 8 & 0 & 0 & 0 & 0 & 0 & 0 & 0 & 0 & 0 & 0 & 0 & 0 \\
\hline $\begin{array}{l}\text { ДО } \\
60\end{array}$ & $\begin{array}{c}3 \\
(100 \%)\end{array}$ & 0 & 0 & 0 & $\begin{array}{c}3 \\
(100 \%)\end{array}$ & 0 & 0 & 0 & $\begin{array}{c}3 \\
(100 \%)\end{array}$ & 0 & $\begin{array}{c}2 \\
(100 \%)\end{array}$ & 0 \\
\hline$>60$ & $\begin{array}{c}1 \\
50 \% \\
\end{array}$ & $\begin{array}{c}1 \\
50 \% \\
\end{array}$ & $\begin{array}{l}0 \\
0\end{array}$ & $\begin{array}{c}4 \\
100 \%\end{array}$ & $\begin{array}{c}2 \\
100 \%\end{array}$ & $\begin{array}{l}0 \\
0\end{array}$ & $\begin{array}{l}0 \\
0\end{array}$ & $\begin{array}{c}3 \\
100 \%\end{array}$ & $\begin{array}{c}1 \\
100 \% \\
\end{array}$ & $\begin{array}{l}0 \\
0\end{array}$ & $\begin{array}{c}1 \\
33,3 \% \\
\end{array}$ & $\begin{array}{c}2 \\
66,7 \%\end{array}$ \\
\hline
\end{tabular}

Примітки: Вікові групи: 1 - 20-29 років, 2 - 30-39 років, 3 - 40-49 років, 4 - 50-59 років, 5 - 60-69 років, 6 - 70-79 років, 7 - 80-89 років, 8 - 90 і більше років. Схеми АБ: №1 - пеніциліни+фторхінолони; №2 цефалоспорини+фторхінолони; №3 - фторхінолони; №4 - цефалоспорини; №5 - карбапенеми; №6 - інші.

Карбапенеми призначались 5 хворим, всі дані хворі одужали. Доба призначення антибіотиків з групи карбапенемів та схем, куди входять дані препарати - $\mathrm{Me}=14$ доба $\left(\mathrm{Q}_{25}=10, \mathrm{Q}_{75}=17\right), \min =8, \quad \max =23$ доба. Тривалість призначення антибіотиків $-\mathrm{Me}=9$ діб $\left(Q_{25}=6, Q_{75}=11\right), \min =5, \max =11$ діб.
Цефалоспорини призначались 23 хворим, 3 них 16 хворим, які померли, та 7 хворим, які одужали. Середня доба призначення антибіотиків 3 групи цефалоспоринів та схем, куди входять дані препарати $-\mathrm{Me}=9$ доба $\left(\mathrm{Q}_{25}=7, \mathrm{Q}_{75}=16\right), \min =2$, $\max =23$ доба. Препарати призначались тим, 
хто одужав - на $\mathrm{Me}=10$ добу $\left(\mathrm{Q}_{25}=7, \mathrm{Q}_{75}=16\right)$, $\min =3, \max =17$ добу; тим, хто помер $-\mathrm{Me}=9$ $\left(Q_{25}=6, \quad Q_{75}=16\right), \quad \min =2, \quad \max =23$ добу. Тривалість призначення - $\mathrm{Me}=7$ діб $\left(\mathrm{Q}_{25}=4\right.$, $\mathrm{Q}_{75}=10$ ), $\min =2$, $\max =13$ діб. Температура на момент призначення - $\mathrm{Me}=36,7^{\circ} \mathrm{C}\left(\mathrm{Q}_{25}=36,3^{\circ} \mathrm{C}\right.$, $\left.\mathrm{Q}_{75}=37,6^{\circ} \mathrm{C}\right), \min =36^{\circ} \mathrm{C}, \max =38,3^{\circ} \mathrm{C}$. Тривалість температури на фоні антибактеріальної терапії $-\mathrm{Me}=0$ діб $\left(\mathrm{Q}_{25}=0, \mathrm{Q}_{75}=1,5\right), \min =0$, $\max =5$ діб. Сатурація на момент призначення антибактеріального лікування - Ме = 93\% $\left(Q_{25}=90 \%, Q_{75}=95 \%\right), \min =70 \%$, max $=97 \%$. Доба нормалізації сатурації на фоні комбінованого лікування, куди входила антибактеріальна терапія $-\mathrm{Me}=0$ доба $\left(\mathrm{Q}_{25}=0, \mathrm{Q}_{75}=5\right), \min =0$, $m a x=8$ діб. Частота дихання в день призначення антибактеріального лікування $\mathrm{Me}=20 / \mathrm{xв} \quad\left(\mathrm{Q}_{25}=20, \quad \mathrm{Q}_{75}=24\right), \quad \min =16$, $\max =32 / \mathrm{xв}$. Нормалізація частоти дихання відбувалась до 6 діб. Частота пульсу в день призначення лікування $-\mathrm{Me}=80 / \mathrm{xв}\left(\mathrm{Q}_{25}=68\right.$, $\left.\mathrm{Q}_{75}=82\right), \min =58, \max =107 /$ хв. Нормалізація частоти пульсу частіше протягом 3 діб, максимальний термін до 5 діб.

Фторхінолони були призначені 35 хворим, з них 11 хворим, які в наступному померли, та 24 хворим, які одужали. Фторхінолони були призначені окремо, або в складі схем АБ терапії 10 хворим у віці до 60 років, та 25 хворим у віці старше 60 років. Серед осіб у віці до 60 років, яким фторхінолони були призначені окремо, або в складі схем АБ терапії, одужало 10 хворих, померлих не було. Серед осіб у віці старше 60 років, яким фторхінолони були призначені окремо, або в складі схем АБ терапії, одужало 14, померло 11 хворих.

Середня доба призначення антибіотиків з групи фторхінолонів та схем, куди входять дані препарати - $\mathrm{Me}=13$ доба $\left(\mathrm{Q}_{25}=9, \mathrm{Q}_{75}=16\right)$, $\min =3, \max =24$ доба. Препарати у хворих, які одужали, призначались в наступні терміни $\mathrm{Me}=13$ доба $\left(\mathrm{Q}_{25}=9,5, \mathrm{Q}_{75}=16,5\right), \mathrm{min}=3, \max =24$ добу, а хворим, які померли, препарат призначався на $\mathrm{Me}=12$ добу $\left(\mathrm{Q}_{25}=9, \mathrm{Q}_{75}=14\right)$, $\min =5, \max =18$ добу.

Доба призначення антибіотиків з групи фторхінолонів та схем, куди входять дані препарати, хворим у віці до 60 років та які

\section{Висновки}

1. Встановлено менше летальних випадків у тяжкохворих із COVID-19, які до госпіталізації приймали антибіотики, в порівнянні 3 тими, хто антибіотики не приймав. одужали $-\mathrm{Me}=13$ добу $\left(\mathrm{Q}_{25}=9, \mathrm{Q}_{75}=15\right), \min =6$, $\max =19$ добу. Доба призначення антибіотиків з групи фторхінолонів та схем, куди входять дані препарати, хворим у віці старше 60 років та які одужали - $\mathrm{Me}=13$ добу $\left(\mathrm{Q}_{25}=10, \mathrm{Q}_{75}=17\right)$, $\min =3$, $\max =24$ добу. Доба призначення антибіотиків з групи фторхінолонів та схем, куди входять дані препарати, хворим у віці старше 60 років та які померли - $\mathrm{Me}=12$ доба $\left(Q_{25}=9, Q_{75}=14\right), \min =5, \max =18$ доба.

Серед хворих молодше 60 років, які отримували фторхінолони та у яких був лейкоцитоз: померло - 0, одужало - 4; у яких був нормоцитоз: померло - 0, одужало - 4; у яких була лейкопенія: померло - 0, одужав - 1 .

Серед хворих старше 60 років, які отримували фторхінолони та у яких був лейкоцитоз: померло - 3, одужало - 4; у яких був нормоцитоз: померло - 5, одужало - 8; у яких була лейкопенія: померло - 2, одужало - 2 .

Тривалість призначення схем, куди входили фторхінолони - $\mathrm{Me}=7$ діб $\left(\mathrm{Q}_{25}=4\right.$, $\left.\mathrm{Q}_{75}=10\right)$, $\min =2, \max =15$ діб. Температура на момент призначення - $\mathrm{Me}=36,8\left(\mathrm{Q}_{25}=36,4\right.$, $\left.\mathrm{Q}_{75}=37,8\right), \min =35,8, \quad \max =38,8^{\circ} \mathrm{C}$. Тривалість температури на фоні антибактеріальної терапії - Ме = 0 діб $\left(Q_{25}=0, Q_{75}=2\right), \min =0, \max =6$ діб. Сатурація на момент призначення антибактеріального лікування - Ме = 95\% $\left(Q_{25}=92 \%, Q_{75}=97 \%\right), \min =74 \%, \max =99 \%$. Доба нормалізації сатурації на фоні комбінованого лікування, куди входила антибактеріальна терапія - Me = 2 доби $\left(\mathrm{Q}_{25}=0, \mathrm{Q}_{75}=10\right), \min =0$, $\max =16$ діб. Частота дихання в день призначення антибактеріального лікування $\mathrm{Me}=20 / \mathrm{xв} \quad\left(\mathrm{Q}_{25}=18, \quad \mathrm{Q}_{75}=20\right), \quad \min =16$, $\max =28 /$ хв. Нормалізація частоти дихання відбувалась на $\mathrm{Me}=0$ добу $\left(\mathrm{Q}_{25}=0, \mathrm{Q}_{75}=3\right)$, $\min =0, \max =12$ добу. Частота пульсу в день призначення лікування $-\mathrm{Me}=76 / \mathrm{xB}\left(\mathrm{Q}_{25}=70\right.$, $\left.\mathrm{Q}_{75}=86\right), \min =56, \max =110 /$ хв. Нормалізація частоти пульсу $-\mathrm{Me}=0,5$ добу $\left(\mathrm{Q}_{25}=0, \mathrm{Q}_{75}=3\right)$, $\min =0, \max =5$ добу.

Аміноглікозиди отримувало 2 хворих, 3 них один одужав, інший помер. Макроліди отримував тільки один хворий, який в наступному помер. Препарат був призначений на 3 добу хвороби.

2. Із узагальнених даних щодо наслідків лікування із застосуванням антибактеріальних препаратів встановлена більшість летальних наслідків у тих, хто під час лікування отримував антибактеріальні 
препарати. В той же час встановлена дещо менша кількість померлих на фоні COVID-19, яким були призначені під час стаціонарного лікування 8мг або 16мг дексаметазону та антибіотики із наступних схем: пеніциліни+фторхінолони, фторхінолони, карбапенеми.

\section{References}

1. WHO Coronavirus (COVID-19) Dashboard. https://covid19.who.int/

2. Limited Role for Antibiotics in COVID-19: Scarce Evidence of Bacterial Coinfection / Wenjing Wei, Jessica K. Ortwine. https://papers.ssrn.com/sol3/papers.cfm?abstract_id= 3622388

3. Clostridioides difficile in COVID-19 Patients, Detroit, Michigan, USA, March-April 2020 / Avnish Sandhu, Glenn Tillotson, Jordan Polistico, Hossein Salimnia, Mara Cranis, Judy Moshos, Lori Cullen, Lavina Jabbo, Lawrence Diebel, Teena Chopra// Emerg Infect Dis. $2020 \quad$ Sep; $26(9)$ : 2272-2274. https://www.ncbi.nlm.nih.gov/pmc/articles/PMC7454 $075 /$

4. Co-infections among patients with COVID-19: The need for combination therapy with non-anti-SARS-CoV2 agents? / Chih-Cheng Lai, Cheng-Yi Wang, Po-Ren Hsueh // J Microbiol Immunol Infect. 2020 Aug; 53(4): 505-512. [електронний ресурс] - Режим доступу: https://www.ncbi.nlm.nih.gov/pmc/articles/PMC7245 213/

5. Waqas Ahmed Chauhdary, Pui Lin Chong, Babu Ivan Mani, Rosmonaliza Asli, Riamiza Natalie Momin, Muhammad Syafiq Abdullah, Vui Heng Chong (2020). Primary Respiratory Bacterial Coinfections in Patients with COVID-19. Am J Trop Med Hyg. Aug; 103(2): 917919.

https://www.ncbi.nlm.nih.gov/pmc/articles/PMC7410 441/
3. Потребує подальшого ефеективність раннього антибактеріальних дослідження призначення препаратів (пеніциліни+фторхінолони, фторхінолони) у тяжкохворих та хворих із середньою тяжкістю. Слід розробити критерії призначення антибактеріальної терапії.

6. Bacterial co-infection and secondary infection in patients with COVID-19: a living rapid review and metaanalysis / Bradley J.Langford, MirandaSo, Sumit Raybardhan, Valerie Leung, Duncan Westwood, Derek R.MacFadden, Jean-Paul R.Soucy, Nick Daneman //Clinical Microbiology and Infection

Volume 26, Issue 12, December 2020, Pages 16221629. [електронний ресурс] - Режим доступу: https://www.sciencedirect.com/science/article/abs/pi i/S1198743X20304237

7. The microbial coinfection in COVID-19 / Xi Chen, Binyou Liao, Lei Cheng, Xian Peng, Xin Xu, Yuqing Li, Tao Hu, Jiyao Li, Xuedong Zhou, Biao Ren // Appl Microbiol Biotechnol. 2020 Aug 11 : 1-9. https://www.ncbi.nlm.nih.gov/pmc/articles/PMC7417 782/

8. The microbial coinfection in COVID-19 / Xi Chen, Binyou Liao, Lei Cheng, Xian Peng, Xin Xu, Yuqing $\mathrm{Li}$, Tao $\mathrm{Hu}$, Jiyao Li, Xuedong Zhou, ${ }^{1,2}$ and Biao Ren // Appl Microbiol Biotechnol. 2020 Aug 11: 1-9. https://www.ncbi.nlm.nih.gov/pmc/articles/PMC7417 $782 /$

9. Early administered antibiotics do not impact mortality in critically ill patients with COVID-19 /Niccolò Buetti, Timothy Mazzuchelli, Elia Lo Priore, Carlo Balmelli, Michael Llamas, Micol Pallanza, Luigia Elzi, Vera Consonni, Pierpaolo Trimboli, Valentina ForniOgna, Enos Bernasconi// J Infect. 2020 Aug; 81(2): e148-e149.

https://www.ncbi.nlm.nih.gov/pmc/articles/PMC7274 $112 /$

\title{
ЭФФЕКТИВНОСТЬ АНТИБАКТЕРИАЛЬНОЙ ТЕРАПИИ У ТЯЖЕЛОБОЛЬНЫХ COVID-19 В ЗАВИСИМОСТИ ОТ ВОЗРАСТА БОЛЬНЫХ И ДОЗ ГОРМОНАЛЬНЫХ ПРЕПАРАТОВ
}

\author{
Трихлеб В.И., Лысенко Т.И., Ерошенко А.А., Мартынчик А.С., \\ Цюрак Н.Р., Беляева К.П.
}

Украинская военно-медицинская академия, г. Киев, Украина

Вступление. В статье представлен обзор литературы по ко-инфекциям при коронавирусной инфекции COVID-19 и приведены данные личного исследования по антибактериальной терапии у тяжелобольных при COVID-19.

Цель. Установить эффективность антибактериальной терапии при лечении новой коронавирусной инфекции COVID-19 у тяжелобольных, которые лечились в ОРИТ, на фоне различных доз гормональной терапии и различных схем антибактериальной терапии.

Материалы и методы: обработанны данные 112 медицинских карт стационарного больного больных с тяжелым течением новой коронавирусной болезнью COVID-19, которые лечились в ОРИТ НВМКЦ «ГВКГ» в период с января по апрель 2021 г. У всех пациентов была обнаружена пневмония с помощью рентгенографии органов грудной клетки или компьютерной томографии. У всех больных диагноз был подтвержден с помощью ПЦР в реальном времени с выявлением PHК SARS-COV-2. Cтатистическая обработка материалов исследования проводилась $c$ помощью персонального компьютера $c$ использованием программы STATISTICA. Была разработана анкета для ввода данных в программу Ехсеl. 
Результаты. В статье представлен обзор литературы по ко-инфекции при коронавирусной инфекции COVID-19, и приведены данные личного исследования по антибактериальной терапии у тяжелобольных при COVID-19. Установлено, что среди тяжелобольных, которые до госпитализации принимали антибиотики, зарегистрировано меньшее количество летальных случаев (9,1\%), чем у тех, кто антибиотики не принимал (29,3\%). В стационаре антибиотики назначали в срок позже 9 суток заболевания, продолжительностью около 7 суток. Преимущественно тяжелобольным в реанимации назначались либо один, либо два антибиотика. В нашей выборке умерших в возрасте до 60 лет не было. По нашим данным больше было выздоровевших больных при применении следующих схем антибактериальной терапии: пенициллины + фторхинолоны; фторхинолоны; карбапенемы. У больных, получавших, кроме антибиотиков, 8 мг дексаметазона, меньше умерло на фоне применения: пенициллины + фторхинолоны; цефалоспорины + фторхинолоны; карбапенемы. У других больных, получавших, кроме антибиотиков, 16 мг дексаметазона, меньше умерло на фоне применения: пенициллины + фторхинолоны; фторхинолоны; карбапенемы. Сделан вывод о необходимости дальнейших исследований эффективности раннего назначения антибактериальных препаратов (пенициллины + фторхинолоны, фтторхинолоны) у тяжелобольных и со средней тяжестью, и разработке критериев назначения антибактериальной терапии.

Выводы. Установлено меньшее число летальных исходов у тяжелобольных с COVID-19, которые до госпитализации принимали антибиотики, по сравнению с теми, кто антибиотики не принимал. $C$ обобщенных данных о последствиях лечения с применением антибактериальных препаратов, установлено большее число летальных исходов у тех, кто во время лечения получал антибактериальные препараты. $B$ то же время, установлено несколько меньшее количество умерших на фоне COVID-19, которым были назначены во время стационарного лечения 8 мг или 16 мг дексаметазона и антибиотики по следующим схемам: пенициллины + фторхинолоны, фторхинолоны, карбапенемы. Требует дальнейшего исследования эффективность раннего назначения антибактериальных препаратов (пенициллины + фторхинолоны, фторхинолоны) у тяжелобольных и больных со средней тяжестью. Следует разработать критерии назначения антибактериальной терапии.

Ключевые слова: COVID-19, тяжелобольные, антибактериальная терапія

\title{
EFFECTIVENESS OF ANTIBIOTIC THERAPY IN CRITICALLY ILL COVID-19 PATIENTS DEPENDING ON AGE OF PATIENTS AND DOSES OF HORMONAL DRUGS
}

\author{
V.I. Trykhlib, T.I. Lysenko., A.A. Yeroshenko, A.S.Martynchyk, N.R. Tsiurak, K.P. Beliaieva
}

\author{
Ukrainian Military Medical Academy, Kyiv, Ukraine
}

Introduction. The article presents a review of the literature on co-infections in COVID-19 coronavirus infection and presents data from a personal study on antibiotic therapy in critically ill patients with COVID-19.

Objective. To establish the effectiveness of antibiotic therapy in the treatment of the new coronavirus infection COVID-19 in critically ill patients who were treated in the ICU, against the background of various doses of hormonal therapy and various antibiotic therapy regimens.

Materials and methods. The data of 112 medical records of an inpatient, patients with a severe course of the new coronavirus disease COVID-19, who were treated in the ICU of the NMMCC "MMCH" in the period from January to April 2021 were processed.

All patients were diagnosed with pneumonia by chest $x$-ray or computed tomography. In all patients the diagnosis was confirmed by real-time PCR with the detection of SARS-COV-2 RNA. Statistical processing of research materials was carried out using a personal computer using the STATISTICA program. A questionnaire was developed for entering data into Excel.

Results.The article presents a review of the literature on co-infection in COVID-19 coronavirus infection and presents data from a personal study on antibiotic therapy in critically ill patients with COVID-19. It was found that there were fewer fatal cases (9.1\%) among critically ill patients who took antibiotics before hospitalization than among those who did not take antibiotics (29.3\%). In the hospital, antibiotics were prescribed later than 9 days of the disease, lasting about 7 days. Predominantly severely ill patients in the intensive care unit were prescribed either one or two antibiotics. There were no deaths under 60 years of age in our sample. According to our data, there were more patients who recovered when using the following antibiotic regimens: penicillins + fluoroquinolones; fluoroquinolones; carbapenems. In patients who received, in addition to antibiotics, $8 \mathrm{mg}$ of dexamethasone, fewer died on the following regimens: penicillins + fluoroquinolones; cephalosporins + fluoroquinolones; carbapenems. In other patients who received, in addition to antibiotics, $16 \mathrm{mg}$ of dexamethasone, fewer died on the background of the use of: penicillins + fluoroquinolones; fluoroquinolones; carbapenems. It is concluded that further research on the effectiveness of early prescription of antibacterial drugs (penicillins + fluoroquinolones, fluoroquinolones) in critically ill and moderately ill patients, and the development of criteria for prescribing antibiotic therapy. 
Conclusions. Fewer deaths were found in seriously ill patients with COVID-19 who took antibiotics before hospitalization, compared with those who did not take antibiotics.

From the generalized data on the consequences of treatment with antibacterial drugs, a greater number of deaths were found in those who received antibacterial drugs during treatment. At the same time, a slightly smaller number of deaths were established against the background of COVID-19, who were prescribed $8 \mathrm{mg}$ or $16 \mathrm{mg}$ of dexamethasone and antibiotics during inpatient treatment according to the following schemes: penicillins + fluoroquinolones, fluoroquinolones, carbapenems.

The efficacy of early prescription of antibacterial drugs (penicillins + fluoroquinolones, fluoroquinolones) in critically ill and moderately severe patients requires further research. Criteria for prescribing antibiotic therapy should be developed.

Key words: COVID-19, seriously ill patients, antibiotic therapy

Конфлікт інтересів: відсутній.

Conflicts of interest: authors have no conflict of interest to declare.

\section{Відомості про авторів:}

Трихліб B.I.A,B,D,E,F -доктор медичних наук, професор кафедри військової терапії Української військово-медичної академії, м. Київ

Лисенко T.I.,, ,D - лейтенант м/с, слухач Української військово-медичної академії, м. Київ

Єрошенко А.о. B,C,D - лейтенант м/с, слухач Української військово-медичної академії, м. Київ

Мартинчик О.С. В,C,D - лейтенант м/с, слухач Української військово-медичної академії, м. Київ

Цюрак Н.Р.В,C,D - лейтенант м/с, слухач Української військово-медичної академії, м. Київ

Беляева К.П., ${ }^{\mathrm{B}, \mathrm{D}}$ - лейтенант м/с, слухач Української військово-медичної академії, м. Київ

$A$ - концепція та дизайн дослідження; $B$ - збір даних; $C$ - аналіз та інтерпретація даних;

$D$ - написання статmi; $E$ - редагування статmi; F - остаточне затвердження статті.

\section{Сведения об авторах:}

Трихлеб В.И. - доктор медицинских наук, профессор кафедры военной терапии Украинской военномедицинской академии, г. Киев

Лысенко Т.И. - лейтенант м/с, слушатель Украинской военно-медицинской академии, г. Киев Ерошенко А.А.- лейтенант м/с, слушатель Украинской военно-медицинской академии, г. Киев Мартинчик А.С.- лейтенант м/с, слушатель Украинской военно-медицинской академии, г. Киев Цюрак Н.Р.- лейтенант м/с, слушатель Украинской военно-медицинской академии, г. Киев

Беляева Е.П.- лейтенант м/с, слушатель Украинской военно-медицинской академии, г. Киев

\section{Information about the authors:}

Trykhlib V.I. A, B, D, E, F - Doctor of Medical Sciences, Professor of the Department of Military Therapy of the Ukrainian Military Medical Academy, Kyiv. https://orcid.org/0000-0001-9250-4385

Lysenko T.I. V, C, D - lieutenant MS, student of the Ukrainian Military Medical Academy, Kyiv Yeroshenko A.A. B, C, D - lieutenant MS, student of the Ukrainian Military Medical Academy, Kyiv

Martynchyk A.S. B, C, D - lieutenant MS, student of the Ukrainian Military Medical Academy, Kyiv

Tsiurak N.R. B, C, D - lieutenant MS, student of the Ukrainian Military Medical Academy, Kyiv

Bieliaieva K.P. B, C, D - lieutenant MS, student of the Ukrainian Military Medical Academy, Kyiv

$A$ - research concept and design; $B$ - collection and/or assembly of data; $C$ - data analysis and interpretation;

$D$ - writing the article; $E$ - critical revision of the article; $F$ - final approval of the article.

Адреса для листування: вул. Московська, 45/1, буд. 33, м. Київ 01015

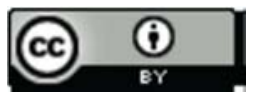

